\title{
CDK5RAP3 wt Allele
}

National Cancer Institute

\section{Source}

National Cancer Institute. CDK5RAP3 wt Allele. NCI Thesaurus. Code C71441.

Human CDK5RAP3 wild-type allele is located in the vicinity of $17 q 21.32$ and is approximately $11 \mathrm{~kb}$ in length. This allele, which encodes CDK5 regulatory subunitassociated protein 3 , is involved in the modulation of cellular proliferation. 